Article

\title{
A New Bromoallene-Producing Chemical Type of the Red Alga Laurencia nangii Masuda
}

\section{Takashi Kamada and Charles Santhanaraju Vairappan *}

Laboratory of Natural Products Chemistry, Institute for Tropical Biology and Conservation, Universiti Malaysia Sabah, 88400 Kota Kinabalu, Sabah, Malaysia;

E-Mail: takashi.k.sugisawa@gmail.com

* Author to whom correspondence should be addressed; E-Mail: csv@ums.edu.my; Tel.: +60-88-320-000 ext. 2397; Fax: +60-88-320-291.

Received: 27 December 2011; in revised form: 8 February 2012 / Accepted: 13 February 2012 / Published: 21 February 2012

\begin{abstract}
Six populations of Laurencia nangii were found to produce three bromoallenes; dihydroitomanallene B (1), itomanallene B (2) and pannosallene (3). Prior to this report, L. nangii were only known to produce $\mathrm{C}_{15}$-acetogenins with acetylene functionality. This could be regarded as a new chemical race of $L$. nangii. The compound structures were elucidated on the basis of spectroscopic analysis and comparison with those previously reported in literature. Compound $\mathbf{1}$, dihydroitomanallene $\mathrm{B}$, was isolated as a new compound representing a minor variation of itomanallene B (2).
\end{abstract}

Keywords: Laurencia nangii; $\mathrm{C}_{15}$-acetogenin; bromoallene; chemical race

\section{Introduction}

The Red algal genus Laurencia (Rhodomelaceae, Ceramiales) is a prolific producer of halogenated secondary metabolites such as sesquiterpenes, diterpenes, triterpenes and $\mathrm{C}_{15}$-acetogenins [1]. Species of this genus are known to produce characteristic sets of halogenated secondary metabolites [2]. However, some species have been reported to produce related or unrelated sets of halogenated metabolites in different populations that are geographically close or distant [3,4]. Several morphologically similar, but chemically distinct, populations have been found in Laurencia nipponica Yamada and Laurencia majuscula (Harvey) Lucas growing in Japan. Thus, the existence of different chemical types of the same species had been suggested as chemical races [2]. 
In an ongoing investigation pertaining to the chemical constituents of red algae genus Laurencia from the coastal waters of Borneo (Malaysia), we reported the chemical composition of L. snackeyi (Weber-van Bosse) Masuda [5], L. similis Nam et Saito [6], L. nangii (Masuda) [7], L. majuscula (Harvey) Lucas [8-11] and Laurencia species [12,13]. Recently, we collected and examined six populations of L. nangii from Tun Sakaran Marine Park, Sabah, Malaysia. These six populations contained different types of halogenated non-terpene metabolites that led us to suggest the presence of "chemical races" in L. nangii of North Borneo Island, Sabah. Each of these populations showed the presence of a new bromoallene [dihydroitomanallene B (1)] along with two known bromoallenes, itomanallene B (2) and pannosallene (3). The structure of the new compound, dihydroitomanallene B (1), was very similar to the known itomanallene B (2) and was elucidated based on spectral data. The structures of known metabolites 2-3 were determined based on the comparison of spectral data of published reports of Suzuki et al. [14] and Suzuki et al. [15]. In this paper, we report the discovery of a bromoallene-producing L. nangii and the structure of compound 1. Compounds $\mathbf{1}$ and $\mathbf{2}$ were very labile in $\mathrm{CDCl}_{3}$, therefore their spectroscopic data were taken in $\mathrm{C}_{6} \mathrm{D}_{6}$. Hence, this paper will describe the isolation and structure elucidation of compound $\mathbf{1}$ and the importance of bromoallenes as chemotaxonomical markers in the red alga L. nangii.

\section{Results and Discussion}

Compound 1 was isolated as a colorless oil, $[\alpha]^{25}{ }_{\mathrm{D}}+64.01^{\circ}\left(\mathrm{CHCl}_{3}\right)$. HR-MS gave a molecular formula of $\mathrm{C}_{17} \mathrm{H}_{25} \mathrm{BrO}_{3}$. The ${ }^{1} \mathrm{H}$ - and ${ }^{13} \mathrm{C}$-NMR signals of 1 showed the presence of a typical terminal bromoallene moiety at $\delta \mathrm{H} 5.66(1 \mathrm{H}, \mathrm{dd}, J=5.8,2.0 \mathrm{~Hz})$ and $5.32(1 \mathrm{H}, \mathrm{dd}, J=5.8,5.8 \mathrm{~Hz}) ; \delta_{\mathrm{C}} 201.5(\mathrm{C})$, $102.6(\mathrm{CH})$ and $73.5(\mathrm{CH})$. The IR spectrum revealed the presence of an acetoxyl group without any hydroxyl groups at $v_{\max } 1,720 \mathrm{~cm}^{-1}$, which was supported by a methyl signal at $\delta \mathrm{H} 1.67(3 \mathrm{H}, \mathrm{s})$ in the ${ }^{1} \mathrm{H}$-NMR spectrum. Detailed ${ }^{1} \mathrm{H}$ and ${ }^{13} \mathrm{C}$-NMR data are given in Table 1 . It is also important to note that data presented in Table 1 was taken in $\mathrm{C}_{6} \mathrm{D}_{6}$ because 1 was easily decomposed when spectra were taken in $\mathrm{CDCl}_{3}$. However, data comparison of 2 with that of Suzuki et al. [14] was done in $\mathrm{CDCl}_{3}$ since 2 was stable in this solvent. Chemical shift data of $\mathbf{1}$ and $\mathbf{2}$ taken in $\mathrm{C}_{6} \mathrm{D}_{6}$ are shown in Table 1.

The planar structure of $\mathbf{1}$ was readily determined as formula 1 (Figure 1) by detailed analysis of ${ }^{1} \mathrm{H}$ - and ${ }^{13} \mathrm{C}-\mathrm{NMR},{ }^{1} \mathrm{H}-{ }^{1} \mathrm{H}$ COSY, HSQC and HMBC spectral data. Moreover, the close resemblance between the $\mathrm{C} 1-\mathrm{C} 10{ }^{1} \mathrm{H}$ and ${ }^{13} \mathrm{C}-\mathrm{NMR}$ data of $\mathbf{1}$ and $\mathbf{2}$, together with co-existence of $\mathbf{1}$ and $\mathbf{2}$ in same alga indicated that $\mathbf{1}$ has the same chiral centers at C4, C6 and C7 as $\mathbf{2}$ and also the double bond at C9-C10 is in the Z-configuration. The bromoallenic moiety of $\mathbf{1}$ was also assigned as $S$ from the strong positive rotation by application of Lowe's rule [16].

The co-existence of dihydroitomanallene B (1), itomanallene B (2) and pannosallene (3) in Malaysian L. nangii, and itomanallene B (2) and itomanallene A (4) in Japanese Laurencia intricate Lamouroux strongly suggested that these four bromoallenes would have the same absolute configurations at $\mathrm{C} 4$, $\mathrm{C} 6$ and $\mathrm{C} 7$. The halogenated $\mathrm{C}_{15}$-acetogenins isolated from various Laurencia have been assumed to arise from common precursors, $(6 R, 7 R)$ or $(6 S, 7 S)$-laurediol (5) [17]. Hence, dihydroitomanallene B (1) may arise from $(6 R, 7 R)$ or $(6 S, 7 S)$-12,13-dihydrolaurediol (6) [18]. Bromonium ion-catalyzed cyclization between the hydroxyl group at $\mathrm{C} 7$ and $\mathrm{C} 4$ in $(6 R, 7 R)$ or $(6 S, 7 \mathrm{~S})$-laurediol (5) would give a monocyclic bromoallene (6) with $(4 R, 6 R, 7 R)$ or $(4 S, 6 S, 7 S)$-configuration. As described by 
Kikuchi et al. [19], the configurations between $\mathrm{C} 12$ and $\mathrm{C} 13$ of $\mathrm{C}_{15}$-acetogenins are $(12 R, 13 S)$ or $(12 S, 3 R)$-erythro, reflecting the $(12 E)$-double bond in both precursors, $(6 R, 7 R)$-laurediols and (6S,7S)-laurediols. Pannosallene (3) and itomanallene A (4) could be biosynthesized from 6 by $(12 R, 13 R)$-bromonium ion-catalyzed cyclization, via route $\boldsymbol{a}$ and $\boldsymbol{b}$ respectively, as shown in Scheme 1. Compound 6 would further afford itomanallene B (2) via acetylation. Similarly, bromonium ion-catalyzed cyclization between the hydroxyl group $\mathrm{C} 7$ and $\mathrm{C} 4$ in $(6 R, 7 R)$ or $(6 S, 7 S)-12,13$ dihydrolaurediol (7) would give a bromoallene (8), which would lead to the formation of dihydroitomanallene B (1) via acetylation. Thus, the absolute configurations of dihydroitomanallene B (1) and itomanallene B (2) would be $4 R, 6 R$ and $7 R$ or $4 S, 6 S$ and $7 S$ as in the case of pannosallene (3) and itomanallene A (4). The relative configuration between $\mathrm{C} 3$ and $\mathrm{C} 4$ remains unclear.

Figure 1. Bromoallene compounds 1, 2, 3 and 4.
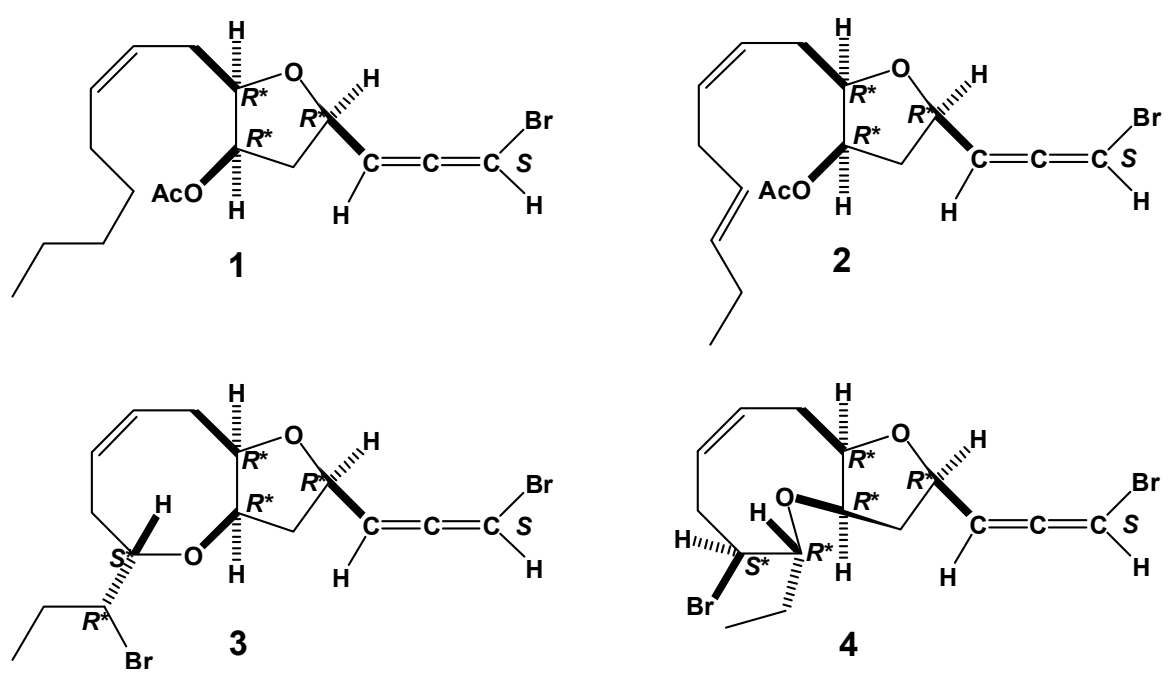

Scheme 1. Biogenesis pathway of compounds 1, 2, 3 and 4.

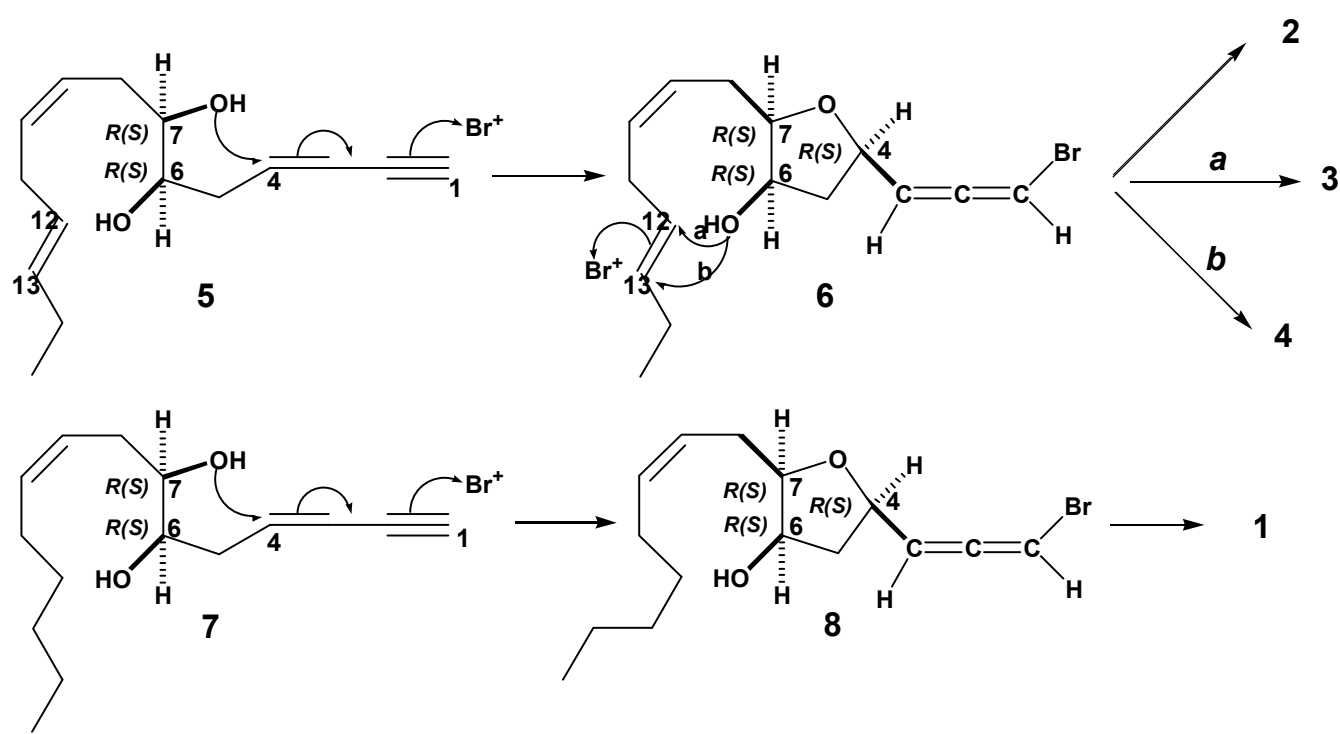

There are close to 50 species of Laurencia in this genus, that could be distinguished based on their morphological features and the type of halogenated metabolites they produce. Approximately 500 types of halogenated metabolites have been isolated and they are useful chemotaxonomic markers in 
taxonomical classification of this genus $[1,16,19]$. In the Malaysian coastal waters, there are four major species of Laurencia; L. snackeyi, L. majuscula, L. similis and L. nangii. They are morphologically distinguishable and could be identified by the halogenated secondary metabolites they produce. Laurencia snackeyi produces halogenated snyderane sesquiterpenes, L. majuscula produces halogenated chamigranes, while, $L$. similis produces polybrominated indoles $[5,6,8-10]$.

Information on the chemistry of $L$. nangii is very scarce and only two other publications are available, both reporting $\mathrm{C}_{15}$-acetogenins with acetylenic functionalities as the halogenated metabolites produced [7,20]. Masuda originally described a type of $L$. nangii based on several specimens collected from Vietnam. It is a tropical alga with a wide distribution in the South East Asian waters, has been reported to be growing wild in Vietnam, Philippines, Indonesia and Malaysia [21]. During our routine field collection, we discovered six populations of L. nangii in Tun Sakaran Marine Park (South East of North Borneo Island) that produces these three bromoallenes. Compound 1, dihydroitomanallene B, is a new unstable compound with minor chemical differences with itomanallene B (2). Itomanallene B (2) was first isolated from L. intricate by Suzuki et al. [14], while panasallene (3) was isolated from Laurencia pannosa Zanardini collected from Vietnam [15]. Both these specimen are morphologically different from $L$. nangii. Two other reports on L. nangii, reported $\mathrm{C}_{15}$-acetogenins, cis-pinnatifidenyne (9), obtusenyne (10), 3(Z)-laurenyne (11) and cis-dihydrorhodophytin (12) (Figure 2) as its halogenated metabolite [7,19]. Masuda et al. also reported aplysiadiol as a constituent of $L$. nangii. However, upon reexamination, it was apparent that it was a contamination from Laurencia sp. that was found growing between thallus of $L$. nangii. To the best of our knowledge, this is the first report of a type of L. nangii that only produces bromoallene as its secondary metabolites. Hence, it is suggested this could be a new chemical race of $L$. nangii.

Figure 2. $\mathrm{C}_{15}$-acetogenin compounds $9, \mathbf{1 0}, 11$ and 12.
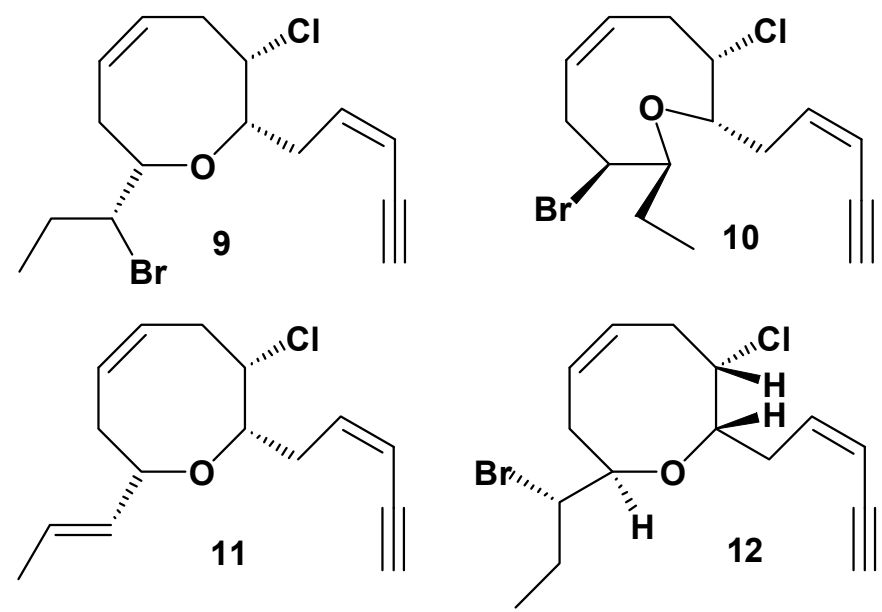

\section{Experimental}

\subsection{General}

Optical rotations were measured on an AUTOPOL IV automatic polarimeter (Rudolph Research Analytical, Hackettstown, NJ, USA). ${ }^{1} \mathrm{H}-\mathrm{NMR}(600 \mathrm{MHz})$ and ${ }^{13} \mathrm{C}-\mathrm{NMR}(150 \mathrm{MHz})$ spectra were recorded with a JEOL ECA 600, with TMS as internal standard. HR-ESI-TOFMS spectrum was 
obtained with LCMS-IT-TOF (Shimadzu, Kyoto, Japan). Preparative TLC was performed with silica gel plate (Merck, Frankfurt, Germany; Kieselgel $60 \mathrm{~F}_{254}$ ). Silica gel (Merck, Kieselgel 60, 70-230 mesh) was used for column chromatography. Analytical TLC was performed on Merck Kieselgel $60 \mathrm{~F}_{254}$. Spots were visualized by UV light or by spraying with a 5\% phosphomolybdic acid-ethanol solution.

\subsection{Biological Material}

The specimen of L. nangii was collected from Tun Sakaran Marine Park, Sabah $\left(5^{\circ} 19^{\prime} 58^{\prime \prime} \mathrm{N}\right.$, $115^{\circ} 12^{\prime} 02^{\prime \prime E}$ ), between 12-28 October 2010. Collected specimens were transported at $4{ }^{\circ} \mathrm{C}$, and air-dried at the laboratory. The voucher herbariums (MAR45943BOR) were made and deposited in the BORNEENSIS Collection of Institute for Tropical Biology and Conservation, Universiti Malaysia Sabah.

\subsection{Extraction and Isolation}

The air-dried Laurencia (400 g) was extracted with $\mathrm{MeOH}$ (1 L) at room temperature for 7 days. The crude extract was evaporated under reduced pressure and the residue was partitioned between $\mathrm{EtO}_{2}$ and $\mathrm{H}_{2} \mathrm{O}$. The $\mathrm{EtO}_{2}$ fraction was further exposed to anhydrous sodium sulphate to remove moisture, and concentrated in vacuo to yield a dark green crude extract. The $\mathrm{EtO}_{2}$ extract (800 mg) was chromatographed on a Si gel column using a hexane and EtOAc gradient of increasing polarity (hex:EtOAc; 9.5:0.5, 9:1, 8:2, 7:3, 6:4, 1:1) as eluant to yield six fractions. A portion of fraction $2(85.8 \mathrm{mg})$ eluted with hexane/EtOAc $(8: 2)$ was submitted to repeated preparative TLC with $\mathrm{CHCl}_{3}$ and toluene to yield compounds $\mathbf{1}(8.4 \mathrm{mg}), \mathbf{2}(5.2 \mathrm{mg})$ and $\mathbf{3}(6.8 \mathrm{mg})$.

\subsection{Dihydroitomanallene B (1)}

Colorless oil; $[\alpha]^{25}{ }_{\mathrm{D}}+64.01^{\circ}\left(\mathrm{CHCl}_{3} ; c\right.$ 0.39); IR $v_{\max }\left(\mathrm{CHCl}_{3}\right) \mathrm{cm}^{-1}: 2910,1720,1350,1240$, 1010, 800; LR-EIMS m/z (rel. int): 315, 313 (3:3) [M-CH$\left.{ }_{3} \mathrm{CO}\right]^{+}, 275$ (32), 273 (32), 247, 245 (16:16) $\left[\mathrm{M}-\mathrm{C}_{8} \mathrm{H}_{15}\right]^{+}, 217$ (18), 111 (25), 43 (100). HR-TOFMS m/z 356.0194 [M] ${ }^{+}$(calcd. for $\mathrm{C}_{17} \mathrm{H}_{25}{ }^{79} \mathrm{BrO}_{3}$, 356.0187); ${ }^{1} \mathrm{H}-\mathrm{NMR}$ and ${ }^{13} \mathrm{C}-\mathrm{NMR}$ spectral data: see Table 1.

Table 1. ${ }^{1} \mathrm{H}-\mathrm{NMR}$ and ${ }^{13} \mathrm{C}-\mathrm{NMR}$ spectral data of compound $\mathbf{1}$ (recorded at $600 / 150 \mathrm{MHz}$ in $\mathrm{C}_{6} \mathrm{D}_{6} ; \delta$ in ppm, $J$ in $\mathrm{Hz}$ ).

\begin{tabular}{ccccc}
\hline $\mathbf{C}$ & & $\mathbf{1}$ & & $\mathbf{2}$ \\
& ${ }^{13} \mathbf{C}$ & $\left.{ }^{\mathbf{H}} \mathbf{H} \boldsymbol{J} \mathbf{~ i n ~ H z}\right)$ & ${ }^{13} \mathbf{C}$ & ${ }^{\mathbf{H}} \mathbf{H} \boldsymbol{J}$ in $\left.\mathbf{H z}\right)$ \\
\hline 1 & 73.5 & $5.66(\mathrm{dd}, J=5.8,2.0 \mathrm{~Hz}, 1 \mathrm{H})$ & 73.6 & $5.67(\mathrm{dd}, J=5.8,2.0 \mathrm{~Hz}, 1 \mathrm{H})$ \\
2 & 201.5 & - & 202.5 & - \\
\hline 3 & 102.6 & $5.32(\mathrm{dd}, J=5.8,5.8 \mathrm{~Hz}, 1 \mathrm{H})$ & 102.6 & $5.31(\mathrm{dd}, J=5.8,5.8 \mathrm{~Hz}, 1 \mathrm{H})$ \\
4 & 74.0 & $4.16(\mathrm{dddd}, J=7.3,5.8,5.4,2.0,1 \mathrm{H})$ & 74.0 & $4.15(\mathrm{dddd}, J=7.3,5.8,5.4,2.0,1 \mathrm{H})$ \\
5 & 38.9 & $1.92(\mathrm{ddd}, J=13.7,5.4,1.5 \mathrm{~Hz}, 1 \mathrm{H})$ & 38.9 & $1.90(\mathrm{ddd}, J=13.7,5.4,1.5 \mathrm{~Hz}, 1 \mathrm{H})$ \\
& & $1.67(\mathrm{~m}, 1 \mathrm{H})$ & & $1.65(\mathrm{~m}, 1 \mathrm{H})$ \\
6 & 73.9 & $5.08(\mathrm{~m}, 1 \mathrm{H})$ & 73.9 & $5.04(\mathrm{~m}, 1 \mathrm{H})$ \\
7 & 81.8 & $3.47(\mathrm{ddd}, J=7.3,7.3,3.4 \mathrm{~Hz}, 1 \mathrm{H})$ & 81.6 & $3.44(\mathrm{ddd}, J=7.3,7.3,3.4 \mathrm{~Hz}, 1 \mathrm{H})$ \\
8 & 27.5 & $2.54(\mathrm{ddd}, J=13.7,7.3,3.4 \mathrm{~Hz}, 1 \mathrm{H})$ & 27.3 & $2.51(\mathrm{ddd}, J=13.7,7.3,3.4 \mathrm{~Hz}, 1 \mathrm{H})$ \\
& & $2.46(\mathrm{ddd}, J=13.7,7.3,3.4 \mathrm{~Hz}, 1 \mathrm{H})$ & & $2.43(\mathrm{ddd}, J=13.7,7.3,3.4 \mathrm{~Hz}, 1 \mathrm{H})$ \\
9 & 124.9 & $5.49(\mathrm{~m}, 1 \mathrm{H})$ & 125.5 & $5.50(\mathrm{~m}, 1 \mathrm{H})$ \\
\hline
\end{tabular}


Table 1. Cont.

\begin{tabular}{ccccc}
\hline $\mathbf{C}$ & & $\mathbf{1}$ & & $\mathbf{2}$ \\
& ${ }^{13} \mathbf{C}$ & ${ }^{\mathbf{1}} \mathbf{H}(\boldsymbol{J}$ in $\mathbf{H z})$ & ${ }^{\mathbf{1}} \mathbf{C}$ & ${ }^{\mathbf{1}} \mathbf{H}(\boldsymbol{J}$ in $\mathbf{~ H z})$ \\
\hline 10 & 132.1 & $5.49(\mathrm{~m}, 1 \mathrm{H})$ & 130.0 & $5.54(\mathrm{~m}, 1 \mathrm{H})$ \\
11 & 27.4 & $2.02(\mathrm{~m}, 2 \mathrm{H})$ & 30.5 & $2.75(\mathrm{br} \mathrm{t}, J=6.8 \mathrm{~Hz}, 2 \mathrm{H})$ \\
12 & 29.4 & $1.30(\mathrm{~m}, 2 \mathrm{H})$ & 127.0 & $5.39(\mathrm{~m}, 1 \mathrm{H})$ \\
13 & 31.5 & $1.22(\mathrm{~m}, 2 \mathrm{H})$ & 132.4 & $5.45(\mathrm{~m}, 1 \mathrm{H})$ \\
14 & 22.7 & $1.24(\mathrm{~m}, 2 \mathrm{H})$ & 25.6 & $1.94(\mathrm{~m}, 2 \mathrm{H})$ \\
15 & 13.9 & $0.87(\mathrm{t}, J=7.3 \mathrm{~Hz}, 3 \mathrm{H})$ & 13.7 & $0.92(\mathrm{t}, J=7.3 \mathrm{~Hz}, 3 \mathrm{H})$ \\
OAc & 169.5 & - & 170.3 & - \\
& 20.4 & $1.67(\mathrm{~s}, 1 \mathrm{H})$ & 20.4 & $1.66(\mathrm{~s}, 1 \mathrm{H})$ \\
\hline
\end{tabular}

\section{Conclusions}

As a part of our chemical investigation on the Bornean red algae genus Laurencia, a new chemical race of $L$. nangii is reported for the first time. A new compound with minor variation from itomanallene B (2) was isolated and identified as dihydroitomanallene B (1). A total of three bromoallenes [dihydroitomanallene B (1), itomanallene B (2) and pannosallene (3)] were isolated and identified from six populations of $L$. nangii collected from Tun Sakaran Marine Park, Semporna, Sabah, Malaysia. This finding has enriched our knowledge on the chemical constituents of Borneon red algae genus Laurencia. Since, chemical race populations of $L$. nangii have not been reported to date, this is the first such finding and suggests this species to consist of at least two chemical races; one that produces $\mathrm{C}_{15}$ acetylenes and another that produces $\mathrm{C}_{15}$ bromoallenes.

\section{Supplementary Materials}

Supplementary materials can be accessed at: http://www.mdpi.com/1420-3049/17/2/2119/s1.

\section{Acknowledgements}

The author (CSV) would like to thank the International Foundation for Science and Organization for the Prohibition of Chemical Weapons for research grant IFS 4836/2. The authors would also like to acknowledge Sabah Parks for assistance during sample collection.

\section{References and Notes}

1. Suzuki, M.; Vairappan, C.S. Halogenated secondary metabolites from Japanese species of the red algal genus Laurencia (Rhodomelaceae, Ceramiales). Curr. Top. Phytochem. 2005, 1-34.

2. Masuda, M.; Abe, T.; Suzuki, T.; Suzuki, M. Morphological and chemotaxanomic studies on Laurencia composita and L. okamurae (Ceramiales, Rhodophyta). Phycologia 1996, 35, 550-562.

3. Masuda, M.; Abe, T.; Sato, S.; Suzuki, T.; Suzuki, M. Diversity of halogenated secondary metabolites in the red alga Laurencia nipponica (Rhodomelaceae, Ceramiales). J. Phycol. 1997, 33, 196-208.

4. Abe, T.; Masuda, M.; Suzuki, T.; Suzuki, M. Chemical races in the red alga Laurencia nipponica (Rhodomelaceae, Ceramiales) Phycol. Res. 1999, 47, 87-95.

5. Tan, K.L.; Matsunaga, S.; Vairappan, C.S. Halogenated chamigranes of red alga Laurencia snackeyi (Weber-van Bosse) Masuda from Sulu-Sulawesi Sea. Biochem. Syst. Ecol. 2011, 39, 213-215. 
6. Vairappan, C.S.; Ang, M.Y.; Ong, C.Y.; Phang, S.M. Biologically active polybrominated indoles in red algae, Laurencia similis from the coastal waters of Sabah (Rhodomelaceae, Ceramiales). Malays. J. Sci. 2004, 23, 119-126.

7. Vairappan, C.S.; Tan, K.L. C-15 Halogenated acetogenin with antibacterial activity against food pathogens. Malays. J. Sci. 2009, 28, 263-268.

8. Vairappan, C.S.; Daitoh, M.; Suzuki, M.; Abe, T.; Masuda, M. Antibacterial halogenated metabolites from the Malaysian Laurencia sp. Phytochemistry 2001, 58, 291-297.

9. Vairappan, C.S. Potent antibacterial activity of Malaysian red algal halogenated metabolites against human pathogenic bacteria. Biomol. Eng. 2003, 20, 255-259.

10. Vairappan, C.S.; Phang, S.M. Morphology and halochamigrene metabolites in Spratly Island species of Laurencia majuscula (Rhodomelaceae, Ceramiales). Malays. J. Sci. 2005, 24, 21-27.

11. Vairappan, C.S.; Sangeetha, P.A.; Tan, K.L.; Matsunaga, S. Role of secondary metabolites as defense chemicals against ice-ice disease bacteria in biofoulers at carrageenophyte farm. $J$. Appl. Phycol. 2010, 22, 305-311.

12. Vairappan, C.S.; Ishii, T.; Tan, K.L.; Suzuki, M.; Zhan, Z. Antibacterial activities of halogenated secondary metabolites from Borneon Laurencia spp. Marine Drug. 2010, 8, 1743-1749.

13. Vairappan, C.S.; Suzuki, M.; Okino, T.; Ishii, T.; Abe, T.; Masuda, M. Antibacterial secondary metabolites from Malaysian Laurencia sp. Phytochemistry 2008, 69, 2490-2494.

14. Suzuki, M.; Takahashi, Y.; Mitome, Y.; Itoh, T.; Abe, T.; Masuda, M. Brominated metabolites from an Okinawan Laurencia intricate. Phytochemistry 2002, 60, 861-867.

15. Suzuki, M.; Takahasi, Y.; Matsuo, Y.; Masuda, M. Pannosallene, a brominated C15 nonterpenoid from Laurencia pannosa. Phytochemistry 1996, 41, 1101-1103.

16. Lowe, G. The absolute configuration of allenes. Chem. Commun. 1965, 411-413.

17. Kurosawa, E.; Fukuzawa, A.; Irie, T. trans- and cis-Laurediol, unsaturated glycols from Laurencia nipponica Yamada. Tetrahedron Lett. 1972, 13, 2121-2124.

18. Fukuzawa, A.; Honma, T.; Takasugi, Y.; Murai, A. Biogenetic intermediates, (3E and 3Z,12Z)laurediols and (3E and 3Z)-12,13-dihydrolaurediols isolated from Laurencia nipponica. Phytochemistry 1993, 32, 1435-1438.

19. Kikuchi, H.; Suzuki, T.; Kurosawa, E.; Suzuki, M. The structure of notoryne, a halogenated C15 nonterpenoid with a novel carbon skeleton from the red alga Laurencia nipponica Yamada. Bull. Chem. Soc. Jpn. 1991, 64, 1763-1775.

20. Masuda, M.; Abe, T.; Kogame, K.; Kawaguchi, S.; Phang, S.M.; Daitoh, M.; Sakai, T.; Takahashi, Y.; Suzuki, M. Taxonomic notes on marine algae from Malaysia. VIII. Three species of Laurencia (Rhodophyceae). Bot. Mar. 2002, 45, 571-579.

21. Masuda, M. A taxonomic study of the genus Laurencia (Ceramiales, Rhodophyta) from Vietnam. IV. Laurencia nangii sp. nov. Cryptogamie Algol. 1997, 18, 309-318.

Sample Availability: Not available.

(C) 2012 by the authors; licensee MDPI, Basel, Switzerland. This article is an open access article distributed under the terms and conditions of the Creative Commons Attribution license (http://creativecommons.org/licenses/by/3.0/). 